\title{
Perancangan Internet Supervisory Control dan Data Acquisition (I -Scada) Universitas Bung Hatta
}

\author{
Febry Rachma Dani*, Feri Candra, Eddy Soesilo \\ Jurusan Teknik Elektro, Fakultas Teknologi Industri, Universitas Bung Hatta \\ Jl. Gajah Mada No. 19 - Padang 15142 \\ rachmadani.febry@gmail.com*,fericandra@gmail.com,soesiloeddy62@yahoo.com
}

\begin{abstract}
Abstrak - I-SCADA merupakan suatu sistem pengendalian alat jarak jauh berbasis web atau menggunakan jaringan internet, dengan kemampuan memantau dan mengendalikan data-data dari alat yang dikendalikan. Teknologi I-SCADA memungkinkan mengontrol dan memonitoring secara langsung kondisi tersebut. Dalam sistem monitoring dan pengontrolan ini dilakukan pengukuran besaran listrik seperti arus, tegangan, daya dan faktor daya serta mengontrol unit-unit beban pada Universitas Bung Hatta Kampus Proklamator III ruangan A11 (IT ROOM). Adapun tujuan penelitian ini adalah untuk membuat alat pengontrol dan monitor energi listrik ruangan A11 (IT Room) Kampus Proklamator III Universitas Bung Hatta dari jarak jauh berbasis web. Alat yang dibuat terdiri dari komponen - komponen seperti sensor arus, sensor tegangan tegangan ,relay, Arduino Mega, Modul Ethernet Shield serta dilengkapi dengan fasilitas server web. Masing-masing komponen diuji sebelum dirangkai menjadi sebuah sistem. Dari hasil enam kali pengujian didapatkan error $0 \%$ dan waktu komunikasi 1.16 detik- 1.30 detik
\end{abstract}

Kata kunci: Arduino,IoT, Ethernet Shield ,I-SCADA

\section{Pendahuluan}

Salah satu upaya untuk menemukan energi alternatif dalam mengurangi kelangkaan energi dari bahan bakar fosil adalah memanfaatkan energi matahari. Pemanfaatan energi matahari dapat dilakukan dengan bantuan panel surya. Panel surya adalah teknologi fotovoltaik yang mengkonversi langsung cahaya matahari menjadi sumber energi listrik dengan menggunakan divais semikonduktor. Harga sel surya relatif mahal dikarenakan membutuhkan teknologi yang canggih dan sukar dalam pengolahan pasir silika menjadi silikon. Saat ini penggunaan sel surya yang dikembangkan kurang optimal dengan tidak terfokuskannya intensitas radiasi pada sel surya.

Pada proses sel surya diperlukan fokus intensitas cahaya matahari yang diterima, karena intensitas mempengaruhi sel surya untuk menghasilkan energi listrik yang optimal. Untuk mengatasi keterbatasan pada panel surya dalam memfokuskan intensitas radiasi, maka di butuhkan lensa Fresnel agar lebih terfokuskan dan dikonversikan manjadi energi listrik dengan efesien dan optimal oleh sel surya.

\section{Dasar Teori}

Listrik yang ada di alam disebabkan karena adanya muatan listrik, pergerakan muatan menimbulkan arus listrik, coulomb adalah satuan yang menyatakan muatan, tujuan dari sebuah rangkaian listrik adalah memindahkan muatan sepanjang lintasan yang diinginkan. Definisi arus itu sendiri adalah laju perubahan muatan persatuan waktu yang diukur dalam satuan ampere (A)[3]. Arus listrik dapat dirumuskan dengan persamaan berikut:

$$
\left[I=\frac{d Q}{d t}\right]
$$

Dimana :

$\mathrm{I}=$ Arus listrik dalam satuan Ampere (A)

$\mathrm{Q}=$ Muatan listrik dalam satuan coulomb (C)

$\mathrm{t}=$ Waktu dalam satuan detik (s)

Arduino merupakan sebuah platform open source (sumber terbuka) yang digunakan untuk membuat proyekproyek elektronika. Arduino terdiri dari dua bagian utama yaitu sebuah papan sirkuit fisik (sering disebut dengan mikrokontroler) dan sebuah perangkat lunak atau IDE (Intergrated Development Environment) yang berjalan pada komputer. Perangkat lunak ini sering disebut Arduino IDE yang digunakan untuk menulis dan mengapload kode dari komputer ke papan fisik (hardware) Arduino.[5][6]

Pada dasarnya pengukuran arus membutuhkan resistor shunt yaitu resistor yang dihubungkan secara seri pada beban dan megubah arus menjadi tegangan. ACS712 merupakan sensor arus yang yang tegangan keluaranya 0$2,5 \mathrm{~V}$ dan sangat cocok digunakan pada mikrokontroler seperti arduino. Teknologi Hall efferct yang diterapkan oleh Allegro menggantikan fungsi resistor shunt dan current transformer menjadi sebuah sensor dengan ukuran yang relatif jauh lebih kecil. Aliran arus listrik yang 
mengakibatkan medan magnet yang menginduksi bagian dynamic offset cancellation dari ACS712. Bagian ini akan dikuatka oleh amplifier dan melalui filter sebelum dikeluarkan melalui kaki 6 dan 7, modul tersebut membantu penggunaan utuk mempermudah instalasi arus ke dalam sistem.

ACS712 adalah Hall Effect current sensor. Hall effect allegro ACS712 merupakan sensor yang presisi sebagai sensor arus AC maupun DC dalam pembacaan arus didalam dunia industri otomotif, komersil dan sistem komunikasi. Pada umumnya aplikasi sensor ini biasanya digunakan untuk mengontrol motor, deteksi beban listrik, switchedmodepowersupplies dan proteksi beban berlebih.

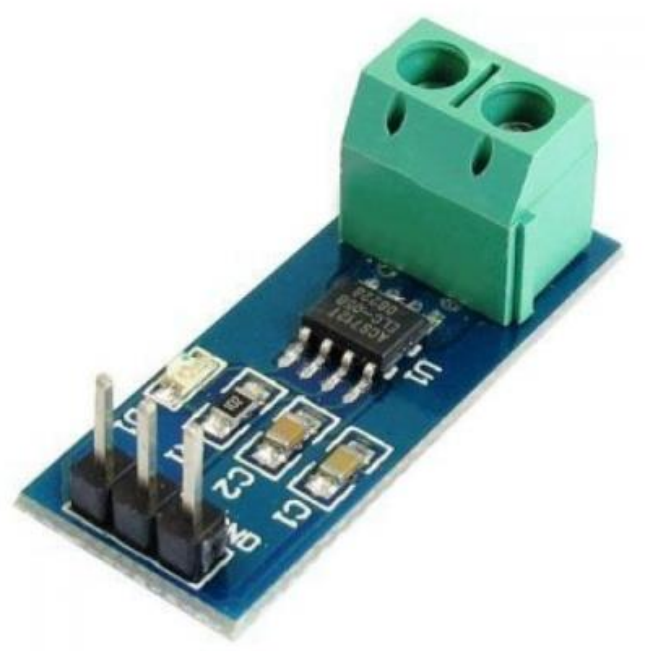

Gambar 1. ACS712

Tegangan listrik adalah besarnya beda energi potensial antara dua buah titik yag diukur dalam satuan volt (V). Tegangan dapat uga diartikan sebagai joule per coulomb [3]. Tegagan didefenisikan sebagai kerja yang diperlukan untuk memindahkan satu unit muatan dari satu terminal ke terminal yang lain:

$$
V=\frac{d W}{d Q}
$$

Dimana $: \mathrm{V}=$ Tegangan dalam satuan volt $(\mathrm{V})$

$\mathrm{W}=$ Energi dalam satuan joule $(\mathrm{J})$

$\mathrm{Q}=$ Muatan dalam satuan coulomb $(\mathrm{C})$

Untuk melakukan pengukuran tegangan tinggi AC, metode yang digunakan adalah dengan cara menurunkan tegangan tinggi ke tegangan rendah. Metode ini yang digunakan dalam pembuatan alat ukur tegangan atau voltmeter. Untuk menurunkan tegangan dapat dilakukan dengan dua cara, yaitu dengan menggunakan rangkaian pembagi tegangan atau yang kedua dengan menggunakan transformator step down. Transformator merupakan suatu peralatan listrik elektromagnetik statis yang berfungsi untuk memindahkan dan mengubah daya listrik dari suatu rangkaian listrik ke rangkaian listrik lainnya, dengan frekuensi yang sama dan perbandingan transformasi tertentu melalui suatu gandengan magnet dan bekerja berdasarkan prinsip induksi elektromagnetik, dimana perbandingan tegangan antara sisi primer dan sisi sekunder berbanding lurus dengan perbandingan jumlah lilitan dan berbanding terbalik dengan perbandingan arusnya [3].

Laju energi yang diserap ataupun yang dikirim disebut daya, sedangkan daya listrik adalah banyak energi listrik yang mengalir setiap detik atau joule per second yang diukur dalam satuan watt (W). daya listrik dirumuskan dengan persamaan berikut [3]

$$
\begin{aligned}
& W=P . t \\
& P=\frac{d W}{d t}
\end{aligned}
$$

Dimana $: \mathrm{P}=$ Daya dalam satuan watt $(\mathrm{W})$

$\mathrm{W}=$ Energi dalam satuan joule $(\mathrm{J})$

$\mathrm{t}=$ Waktu dalam satuan detik (s)

Energi listrik didefenisikan sebagai laju penggunaan daya listrik dikalikan dengan selama waktu tersebut [5]. Satuan SI untuk energi listrik adalah Joule (J), namun dalam kehidupan sehari-hari lebih dikenal dengan kiloWatthour(kWh). Pada sebuah rangkaian listrik, hubungan antara arus dan tegangan dijelaskan dengan hukum ohm dimana arsu berbanding lurus dengan tegangan dan berbanding terbalik dengan hambatan, hambatan yang dimaksud adalah hambatan pada rangkaian yang dapat menghalangi aliran arus. Hambatan dinotasikan dengan $\mathrm{R}$ dan ukur dalam satuan ohm $(\Omega)$.

$$
P=\frac{V}{R}
$$

Dimana $: I=$ Arus dalam satuan ampere (A)

$\mathrm{V}=$ Tegangan dalam satuan volt $(\mathrm{V})$

$\mathrm{R}=$ Hambatan dalam satuan ohm $(\Omega)$

Pada jaringan listrik AC dengan bentuk gelombang sinusoidal dikenal beberapa jenis bentuk daya, diantaranya adalah daya kompleks, daya aktif dan daya reaktif.

Perkalian tegangan $\mathrm{V}$ dengan arus I* dalam kedua besaran ini dalam bentuk kompleks adalah VI* yang dinamakan daya kompleks dengan simbol S, dalam satuan Volt Ampere (VA). Daya aktif atau daya nyata dirumuskan dengan $\mathrm{S} \cos \theta$ atau $\mathrm{VI}^{*} \cos \theta$ dengan simbol $\mathrm{P}$, dalam satuan Watt $(\mathrm{W})$. Sedangkan daya reaktif atau daya khayal dirumuskan dengan $\mathrm{S} \sin \theta$ atau $\mathrm{VI}^{*} \sin \theta$ dengan $\operatorname{simbol} \mathrm{Q}$, dalam satuan Volt Ampere Reaktif (VAR) [3].

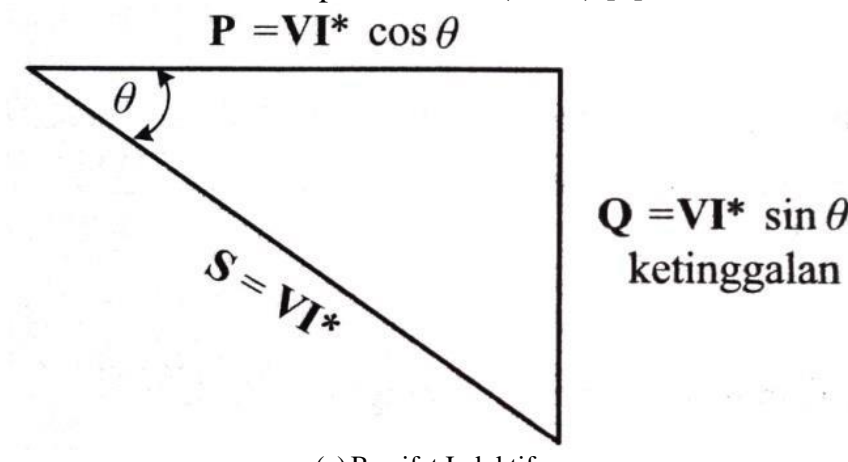

(a) Bersifat Induktif 


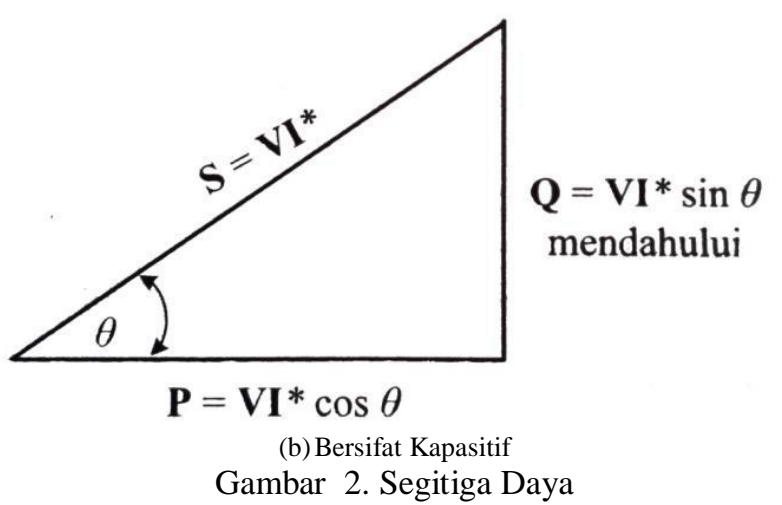

Komponen - komponen segitiga daya dapat dituliskan sebagai berikut :

Daya aktif $: P=V I * \cos \theta_{(\mathrm{W})}$

Daya reaktif $: Q=V I * \sin \theta_{(\mathrm{VAR})}$

Daya semu : $S=V I$ (VA)

Faktor daya : $p f=\cos \theta$

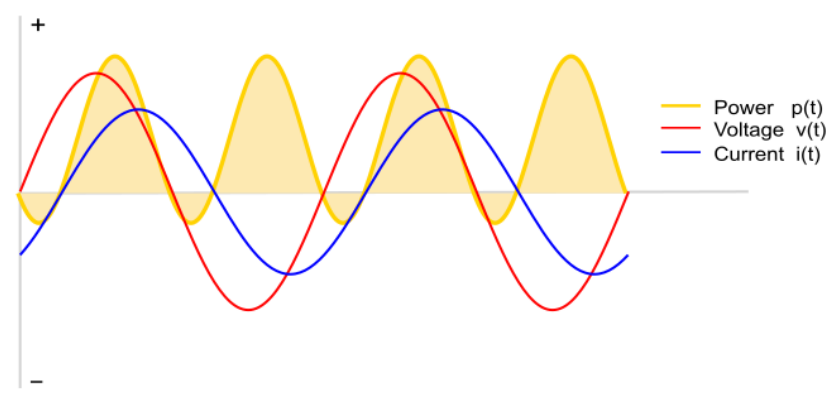

Gambar 3. Hubungan tegangan, arus dan daya beban sebagian reaktif

Tapi pada praktikalnya sebagian besar pasokan daya untuk perangkat DC seperti Laptop, menghasilkan beban non linier kelistrik. Grafik arusnya digambarkan sebagai berikut :

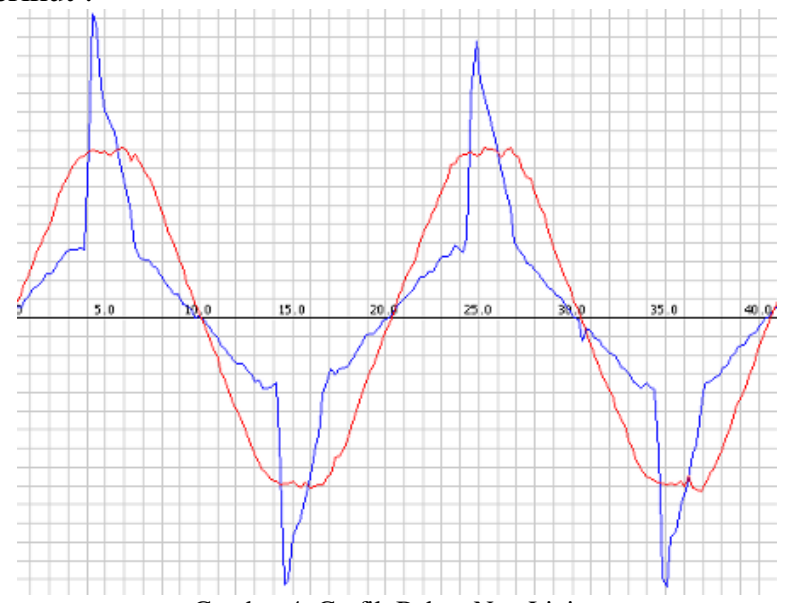

Gambar 4. Grafik Beban Non Linier
XAMPP adalah software yang berfungsi untuk menjalankan website berbasis PHP dengan menggunakan pengolahan data MySQL di komputer local.

Perangkat lunak komputer ini memiliki kelebihan untuk bisa berperan sebagai server web Apache untuk simulasi pengembangan website. Tool pengembangan web ini mendukung teknologi web populer seperti PHP, MySQL, dan Perl. Melalui program ini, programmer web dapat menguji aplikasi web yang dikembangkan dan mempresentasikannya ke pihak lain secara langsung dari komputer, tanpa perlu terkoneksi ke internet. XAMPP juga dilengkapi fitur manajemen database PHPMyAdmin seperti pada server hosting sungguhan, sehingga pengembang web dapat mengembangkan aplikasi web berbasis database secara mudah.

HTML (Hypertext Markup Language) adalah bahasa yang digunakan untuk menuliskan halaman web dan tidak tergantung pada suatu platform tertentu (platform independent). HTML disebut markuplanguage karena mengandung tanda-tanda tag tertentu yang digunakan untuk tampilan suatu dokumen.

Untuk menjalankan HTML harus menggunakan web browser atau browser. Ciri utama dokumen HTML adalah adanya tag elemen. Dokumen HTML mempunyai tiga tag utama yang membentu struktur dari dokumen HTML yaitu HTML, HEAD, dan BODY. Elemen dalam dokumen HTML seperti diatas dikategorikan menjadi dua elemen $<$ HEAD> yang berfungsi memberikan informasi tentang dokumen tersebut dan elemen <BODY> yang menentukan bagaimana isi suatu dokumen ditampilkan oleh browser seperti, paragraph, list (daftar), table dan lain-lain.

PHP (PHP Hypertext Processor) adalah bahasa serverside scripting yaitu bahasa yang berbentuk skrip yang ditempatkan dalam server dan diproses diserver, dapat menyatu dengan HTML untuk membuat halaman web yang dinamis. PHP merupakan software yang open source dan mampu lintas platform. PHP dibangun sebagai modul pada web server Apache dan sebagai binary yang dapat berjalan sebagai CGI.[7]

MySQL adalah Relation Database Management Sistem (RDBMS) yang didistribusikan secara gratis dibawah lisensi GPL (General Public License).[7][8]

MySQL dikembangkan sekitar tahun 1994 oleh sebuah perusahaan pengembang software dan konsultan database bernama MySQL AB yang bertempat di Swedia. MySQL merupakan multiuser database yang menggunakan bahasa Structure Query Language (SQL). SQL adalah bahasa standar yang digunakan untuk mengakses server database.[7][8]

MySQL memiliki banyak tool yang dapat memudahkan untuk administrasi. Sebagai database server yang memiliki konsep database modern, MySQL memiliki banyak keistimewaan. Berikut ini adalah keistimewaan MySQL [8]:

1 Portability

MySQL dapat berjalan stabil ada berbagai sistem operasi diantaranya adalah Windows, Linux, Solaris, dan masih banyak lagi.

2 Open Source 
MySQL didistribusikan secara open source (gratis), dibawah lisensi GPL sehingga dapat digunakan tanpa dipungut biaya.

3 Multiuser

\section{Security}

MySQL memiliki beberapa lapisan sekuritas seperti level subnetmask, nama host, dan izin akses user dengan sistem perizinan yang mendetail serta pasword yang terenskripsi.

5 Scalability

MySQL mampu menangani database dalam skala besar, dengan jumlah record lebih dari 50 juta dan 60 ribu table serta 5 milyar baris.

I-SCADA merupakan singkatan dari Internet Supervisory Control and Data Aquisition. I-SCADA adalah suatu sistem pengendalian alat jarak jauh berbasis web dengan menggunakan jaringan internet, dengan kemampuan memantau dan mengendalikan data-data dari alat yang dikendalikan. I-SCADA mampu mengkombinasi telemetri dan akuisisi data. I-Scada meliputi pengumpulan informasi, membawanya keluar sistem kapan pun dibutuhkan adanya analisis dan pengendalian data serta menampilkan informasinya dalam bentuk seperti angka, gambar, kata-kata, pada sebuah layar dihadapan operator. Tindakan pengontrolan dibutuhkan untuk membawanya kembali kedalam proses.

Sebelum akuisisi data, logika relai digunakan untuk mengendalikan sistem yang berjalan pada plant. Seiring dengan semakin banyaknya hal untuk memonitor dan mengontrol, maka berbagai macam perangkat mulai berkembang, seperti Arduino. Arduino merupakan salah satu perangkat yang bisa digunakan dalam menerapkan sistem I-SCADA. Ada dua elemen dalam aplikasi ISCADA, yaitu:

- Proses, sistem atau mesin yang akan dipantau dan dikontrol

- Sebuah jaringan peralatan 'cerdas' dengan antar muka ke sistem melalui sensor dan luaran kontrol. Dengan jaringan ini, yang merupakan sistem ISCADA, memungkinkan melakukan pemantauan dan pengontrolan komponen-komponen sistem tersebut.

Dalam aplikasinya, subsistem penyusun scada terdiri dari :

1. HMI (Human Machine Interface)

Human Machine Interface (antar muka manusiamesin) adalah subsistem dari I-SCADA yang berfungsi menampilkan data dari hasil pengukuran.

2. MTU (Master Terminal Unit)

Master Terminal Unit merupakan sebuah sistem yang bertugas memberikan data kepada Human Machine Interface (HMI) dari Remote Terminal Unit (RTU). Disisi lain MTU juga bertugas mengambil data dari tiap-tiap RTU (jika RTU lebih dari 1) untuk diterjemahkan dan diberikan ke HMI.

3. RTU (Remote Terminal Unit)

RTU atau Remote Terminal Unit adalah subsistem I-Scada yang berfungsi sebagai terminal-terminal dari hasil pengukuran, pengendalian, pemantauan status dan lain-lain. RTU juga berfungsi menerjemahkan, mengkonversi, menghitung sinyal dari sensor besaran energi listrik.

4. Actuator

Actuator adalah sebuah mekanis untuk menggerakan atau mengontrol sebuah mekanisme atau sistem. Actuator yang digunakan pada penelitian ini ialah relay dan motor servo.

5. Data Acqisition

Dalam hal ini data besarnya arus, tegangan, daya dan faktor daya merupakan data acquisition dan data base yang dapat dilihat pada komputer/PC.

6. Mikrokontroler

Mikrokontroler adalah sebuah kontroler yang diprogram sesuai kebutuhan kita. Mikrokontroler pada sistem I-SCADA biasanya difungsikan pada RTU, jadi mikrokontroler merupakan subsistem RTU. Mikrokontroler ini bertugas melakukan pengolahan /pengambilan data dari sensor.

7. Sistem Komunikasi (Antar MTU dan RTU)

Sistem komunikasi merupakan sebuah cara untuk mengkomunikasikan data dari RTU ke MTU. Sistem komunikasi menggunakan Router wifi dan Ethernet Shield.

Konsep sistem pengawas dan mengontrol via internet memungkinkan pengguna untuk menghubungkan, mengontrol, dan memantau sistem secara langsung melalui internet. Pemantuan harus memberikan informasi yang diperlukan oleh pengguna, informasi harus kompak dengan konsep SMART (Specific, Measurable, Attainable, Relevant, Time-bound) spesifik, terukur, dapat diperoleh, relevan, dalam rentang waktu. (Z. Pei, L. Fangxing dan B. Navin ,)

Banyak yang memanfaatkan realtime monitoring ini secara wireline seperti LCD dan tidak sedikit pula yang memanfaatkan nya secara wireless seperti bluetooth, text massage, dan juga web.

IoT (Internet of Things) dapat digambarkan sebagai koneksi dari perangkat seperti ponsel pintar, komputer pribadi, sensor, dan aktuator melalui jaringan internet, perangkat yang terhubung bisa menghaslkan informasi yang dapat digunakan oleh manusia atau sistem lainya.

\section{Metodologi Penelitian}

Perancangan sistem menggunakan Arduino dan Ethernet Shield sebagai media komuniasi antara Arduino dan Internet. Modem digunakan sebagai fasilitas penyedia jaringan yang terhubung dengan router, antara router dan 
arduino dihubungkan dengan kabel UTP dan RJ45 sebagai konektor.

Untuk mengontrol beban digunakan relay 220/5 V 10A. Jenis beban yang dikontrol antara lain sebagai berikut :

1 Lampu 2 Group

2 AC 2 buah

3 Stop Kontak 1

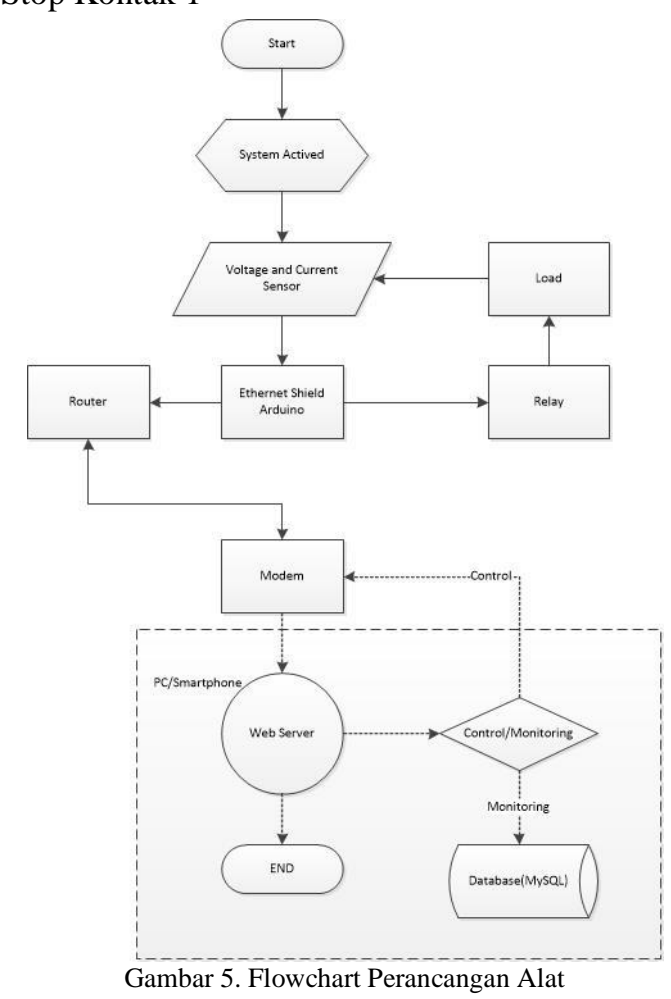

Berdasarkan gambar 5 terlihat bahwa sensor tegangan dan arus mendeteksi ada atau tidaknya beban yang hidup dan memproses data arus dan tegangan di arduino. Data yag diolah (tegangan, arus, faktor daya, dan pemakaian energi) akan dikirimkan ke web server menggunakan media internet melalui ethernet shield dan router. Web server akan mengola data yang diterima dari arduino berdasarkan waktu dan jenis beban.

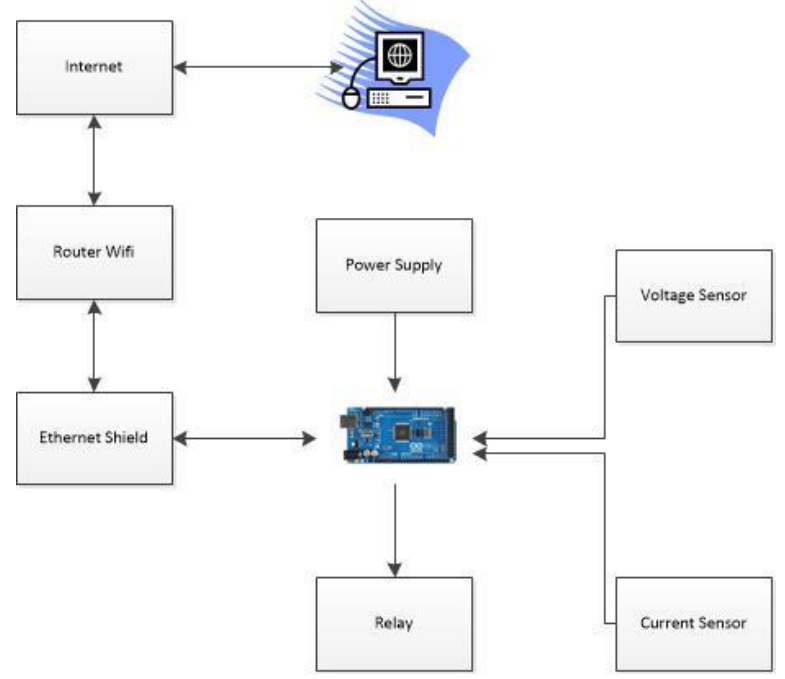

Gambar 6. Blok Diagram Perancangan Sistem

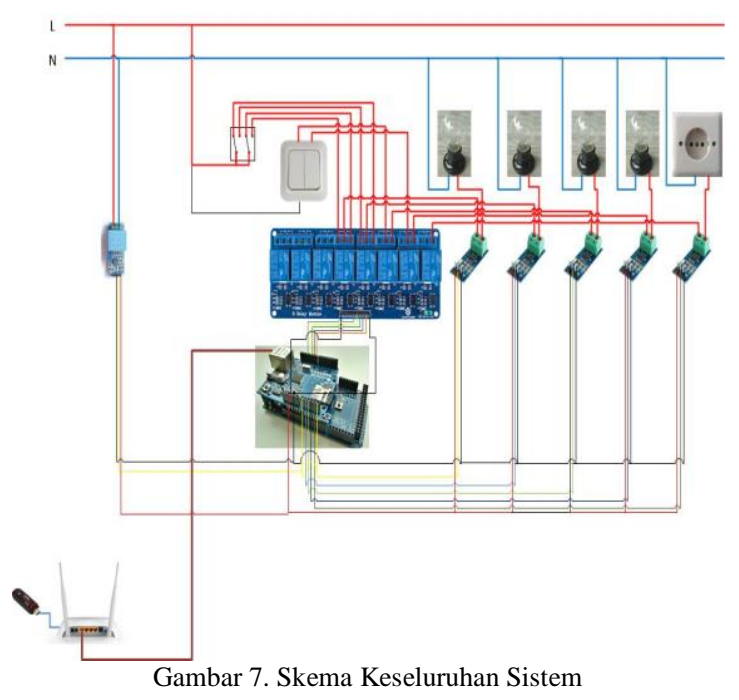

\section{Temuan Dan Pembahasan}

\begin{tabular}{|c|c|c|c|}
\hline \multicolumn{5}{|c}{ Tabel 1 Hasil Pengujian } \\
\hline Pengujian & Berhasil & Tidak & $\begin{array}{c}\text { Waktu } \\
\text { Komunikasi(detik) }\end{array}$ \\
\hline 1 & $\sqrt{ }$ & & 1,18 \\
\hline 2 & $\sqrt{ }$ & & 1,17 \\
\hline 3 & $\sqrt{ }$ & & 1,19 \\
\hline 4 & $\sqrt{ }$ & & 1,25 \\
\hline 5 & $\sqrt{ }$ & & 1,30 \\
\hline 6 & $\sqrt{ }$ & & 1,16 \\
\hline
\end{tabular}
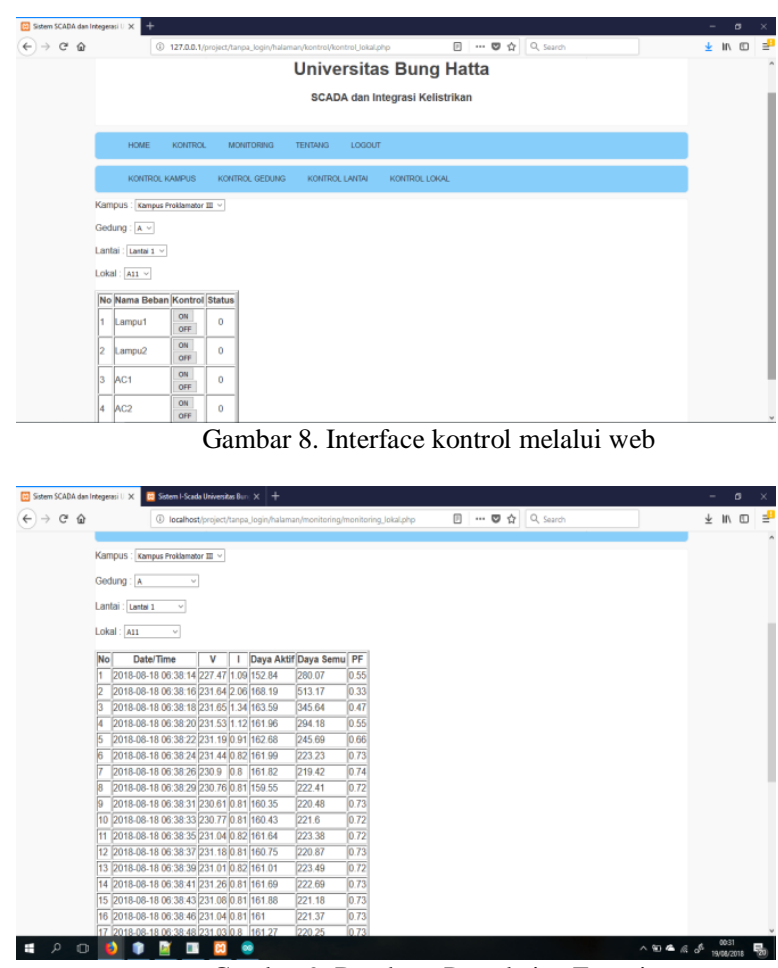

Gambar 9. Database Pemakaian Energi 


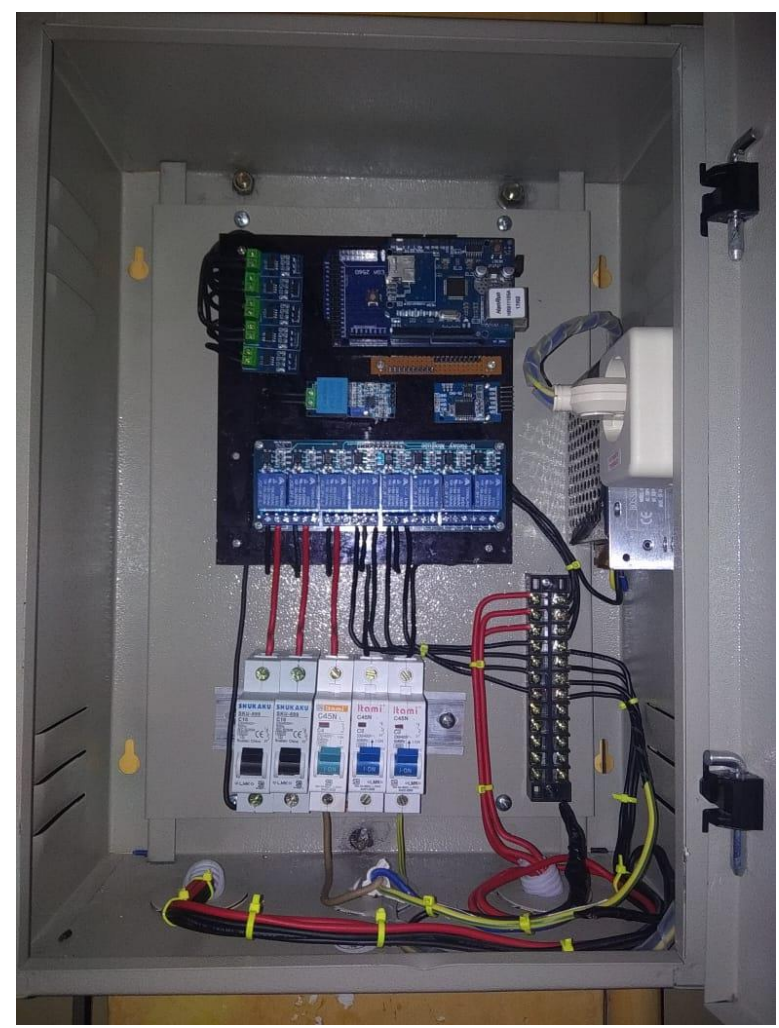

Gambar 10. Pemasangan Alat pada Panel

\section{Simpulan Dan Saran}

Dari hasil penilitia maka penulis memiliki kesimpulan, yaitu:

1. Monitoring Kelistrikan Gedung A ruangan A11 (IT Room) sudah dapat diketahui secara online

2. Kesalahan yang terjadi pada alat perancangan sangat kecil, berkisar antara 0 sampai $1.049 \%$
3. Dengan adanya database pada perancangan ini maka data pemakaian energi listrik dapat di print out

4. Monitoring dan kontrol memanfaatkan router sebagai media komunikasi antara web dan ethernet shield

5. Pengoperasian jarak jauh dapat dilakukan dengan memanfaatkan smartphone dan komputer yang terkoneksi dengan jaringan internet.

6. Apabila Arduino terlalu sering di flash (cabut pasang USB) maka akan menyebabkan port sibuk .

7. Alat ini bisa dipasang di panel mana saja asalkan range arus maksimal $20 \mathrm{~A}$ dan tegangan maksimal Phasa Netral $250 \mathrm{~V}$.

\section{Kepustakaan}

[ 1 ] E. Kagermann, H., W. Wahlster and J. Helbig, "Recommendations for implementing the strategic initiative INDUSTRIE 4.0," no. April, 2013

[2] M. Hermann, T. Pantek, and B. Otto, "Design Principles for Industrie 4.0 Scenarios," Des. Princ. Ind. 4.0 Scenar., no. 01, 2015.

[3] R. J. Fowler, Electricity Principle \& Application, New York : McGraw-Hill, 2008

[ 4 ] W.H. Hayt dan K. Jack E ; Rangkaian Listrik, Jakarta: ANDI, 2013

[5] Ikram,Muhammad.,Suryana, Taryana, "Sistem Penyiraman Tanaman Otomatis Berbasis Mikrokontroler", 2017

[6] Khaidir, Abdul. Buku Pintar Pemograman Arduino. MediaKom, Yogyakarta, 2015

[ 7 ] Solichin, Achmad. Pemograman Web dengan PHP dan MySQL

[ 8 ] Talukdar, Abhijit dkk, "Design of RTU \& SCADA", Assam Don Bosco University, 2016

[ 9 ] Darandale,D.C., Gunjal B.L.,’Development of Web-Based SCADA like Application using Arduino Platform", International Jurnal of Emerging Technology and Advance Engineering, 2013

[ 10 ]Sunanda, Wahri,. Dinata, Irwan,. "Penerapan Wireless Monitoring Energi Listrik Berbasis Arduino dan Internet",Universitas Bangka Belitung, 2014.

[ 11 ] Sirojudding, Muhammad., Wirawan,. Ashari, Mochamad, "Desain Sistem Monitoring dan Kontrol Penggunaan Energi Listrik Menggunakan Wireless Sensor Network”, 2014

[12 ] Alegro ACS712 datasheet 